\title{
Project portfolio management to increase PDAM Tirtawening's service coverage area
}

\author{
S. S. Moersidik ${ }^{1}$, R. S. Arifin ${ }^{1}$, E. T. B. Soesilo ${ }^{2}$, \\ D. M. Hartono ${ }^{1} \&$ Y. Latief ${ }^{1}$ \\ ${ }^{1}$ Faculty of Engineering, University of Indonesia, Indonesia \\ ${ }^{2}$ Graduate Program of Environmental Science, University of Indonesia, \\ Indonesia
}

\begin{abstract}
In most developing countries, the growth of urban public service infrastructure strives to keep up with population growth. Residential Water Use (RWU) in over half of total municipal water consumption in most urban areas in developed countries face similar challenges. For example, consider the Municipality Water Supply Utility (Perusahaan Daerah Air Minum/PDAM) Tirtawening, Bandung; in the last 10 years, the average urban water coverage services have grown at a rate of $0.65 \%$, while the Bandung municipal population growth rate is $1.42 \%$ per year. PDAM select and prioritizes their project portfolio based on Strengths, Weaknesses, Opportunities and Threats (SWOT) analysis as well as on its resources availability.

A significant body of research exists which assesses the tools and techniques to optimize a project portfolio. Project Management Body of Knowledge (PMBOK) $5^{\text {th }}$ edition mentions that project interdependencies is a tool to determine and select the project from the Project Portfolio (PP). Most research conducted treated project interdependencies (PI) as a static variable, defined in earlier stage of the PP lifecycle. Apart from that, the importance of a dynamic PI model that is developed using the System Dynamics (SD) approach is not yet recognized as a tool and technique for project portfolio selection

The outcomes of this research suggest that the project interdependencies model developed through the SD approach can be one of the available tools and techniques used to assess project interdependencies and determine project priority in order to optimize the project portfolio.
\end{abstract}


Keywords: project portfolio management, project management, urban water management, PDAM Tirtawening Bandung, system dynamics.

\section{Introduction}

In many parts of the globe, population growth and urbanization are increasingly becoming a challenge to governments. According to the information from the UN [1], by the year 2020 around $60 \%$ of the global population will live in urban areas. Currently, more than 80 countries accounting for $40 \%$ of the global population suffer from severe water shortages. Urban development in Indonesian cities is worsening compared to other countries because of tremendous population growth in urban areas. Based on Indonesian Public Works Ministry, from a total of 335 Municipal Waterworks (PDAM) throughout Indonesia, 86 PDAMs are considered as unhealthy organizations; one of them is PDAM Tirtawening of Bandung municipality PU [2]. PDAM Bandung municipal drinking water service only reaches $61.1 \%$ of total population, while the minimum Millennium Development Goals (MDG) standard service level is $80 \%$ PU [2] (Zonasi [3]).

One of the most important Key Performance Indicators (KPIs) of PDAM Tirtawening Bandung is to increase the service coverage area. In order to achieve this KPI, every year PDAM Tirtawening selects the upcoming year's projects by conducting a SWOT analysis. This approach is iterated every year but service coverage area targets have never been achieved.

A significant body of research exists which has assessed the tools and techniques to optimize the project portfolio. It's mentioned in PMBOK $5^{\text {th }}$ edition [4] that the tools and techniques used to optimize the portfolio are: 1) Capability and Capacity Analysis; 2) Weighting Ranking and Score Techniques; 3) Quantitative and Qualitative Analysis; and 4) Graphical Analytical Methods. A recently performed literature review shows that the importance of project interdependencies is not yet recognized as a tool and technique to optimize the portfolio. This research proposes using a System Dynamics Approach in developing project interdependencies (PI) within a project portfolio (PP). The outcomes of the study would enhance PDAM's strategic decision-making capabilities.

\subsection{Project Portfolio Management}

A portfolio is a collection of various components including programs, projects, and operations managed as a group to achieve strategic objectives. PMI [5] mentions that the portfolio components may not necessarily be interdependent or have related objectives. The portfolio components are quantifiable; that is, they can be measured, ranked, and prioritized. The project portfolio is the set of projects that an organization is undertaking at any given time PMI [5]. Kersten and Verhoef [6] claim that firms reduce IT expenditure by 10 to 40 percent using Project Portfolio Management (PPM), while Laslo [7] stated that PPM allows an organisation to maintain its agility while avoiding wasteful investments. Since 
organization manages complex and dynamic environments, the PPM should also be able to accommodate these changes in dynamics.

\subsection{Project interdependencies (PI)}

Based on PMI [5], project interdependencies are among the many factors that must be considered in PPM decisions. A project interdependency exists when one project is dependent on other(s), for example through the need to use the end result of another project, the need to incorporate the capabilities and knowledge gained by another project, or the need to wait for scarce resources until they are released by another project. Platje [8] suggests that there is a need for better strategies to manage project interdependencies to develop successful cross-communication capabilities. Furthermore, Ghamsemzadeh and Ancher [9] and Carlsson et al. [10] suggest that resource dependencies are often addressed by scheduling optimization systems. However, the required numerical input is not considered useful in PPM environments due to the extensive volume required by systems that does not provide effective feedback. Numerical methods have also been addressed regarding Net Present Value and other discounted cash flow analysis that are based on time-cost performance triangles that aid in PPM in the short-term, but fail to determine the long-term value of project portfolios due to uncertainty within markets (Carlsson et al. [10], Zapata et al. [11]).

The majority of early research in the field of PPM was focused largely on resource and risk management, as well as on traditional project portfolio management literature topics on project selection and prioritization. However, managing interdependencies is an area of weakness for PPM that deserves further investigation. Rungi and Hilmola [12] confirms this by saying that the project interdependency (PI) concept is less investigated but is an emerging field. Many studies on the importance of project interdependencies have been done as part of other studies [13-15]. Those studies, however, treat the interdependencies among projects as static relationships. The dependencies are determined up front in the initiation or planning process.

To establish a PPM that allows an organization to maintain its required agility caused by the changes in dynamics in its environment, the PI characteristics should also be dynamic.

\subsection{System dynamics}

Forrester pioneered system dynamics during the 1960s as an analytical modeling technique (Srijariya et al. [16], Sterman [17]). In his work, Sterman [17] remarked, "the fundamental principle in system dynamics states that the structure of the system gives rise to its behavior". Systems thinking is a scientific field of knowledge that emphasizes the need to understand change and complexity through the interactions and relationships of different components in a system by studying the dynamic cause and effect over time (Papageorgiou [18]).

Individual components in a system do not themselves contain complex behaviors - it is the interactions between the components that contain the most complex behaviors (Sterman [17]). To analyze the interactions of components in 
a system, the feedback structures must be understood through analysis of cause and effect over time. By understanding feedback loops, system dynamics can be put into action through the assessment of issues from multiple perspectives. The main goal of system dynamics thinking is to challenge initial perspectives and consider the long-term effects of actions chosen that could possibly impact the environment, society or moral beliefs (Sterman [17]).

System dynamics involves a comprehensive set of steps that should be undertaken in order to gain the full benefits that the tool provides to achieve successful outcomes. The tool offers a systematic process to capture and analyze systems. It is proposed that the application of system dynamic modeling may improve the understanding of interdependencies between projects in a project portfolio, and therefore is a useful tool to assist with project portfolio strategic decisions.

\subsection{Case study: Public Waterworks (PDAM) Tirtawening, Bandung municipal}

\subsubsection{Bandung profile}

Bandung is one of Indonesia's biggest cities; it is the capital city of the Province of West Java. The area of Bandung is comprised of 26 districts with a population density of 38,686 persons per $\mathrm{km}^{2}$. The population density grows at an average annual growth rate of $0.92 \%$. Bandung municipal boundaries are: West Bandung regency, Cimahi and Sumedang. The population density of West Bandung regency is 11.471 persons $/ \mathrm{km}^{2}$. Sumedang has 1025 persons $/ \mathrm{km}^{2}$, while Cimahi has 24,067 persons $/ \mathrm{km}^{2}$. The Bandung municipal population is 2,394,873 (58.43\%), Cimahi 1,091,323 (26.63\%) and Sumedang 612,168 (14.94\%) [19].

Many of Bandung's citizens commute between the municipalities and boundaries. In reality, the population active in Bandung municipality is likely to exceed the number of registered residents. The registered population of Bandung grows at a rate of $2.08 \%$ and the GDP grows by $18.84 \%$ annually - rendering the city overcrowded. Urban land has become extremely scarce.

Bandung municipality's economy is made up of the services and processing sectors. The air pollution level exceeds the recommended threshold; especially considering the levels of dust, $\mathrm{HC}$ and $\mathrm{Pb}$. Bandung transportation is facing serious problems and is increasingly becoming a major threat for the future, particularly if there are no significant changes in infrastructure.

Challenged by the complex conditions and the high pace of growth, Bandung municipal public services have become bogged down. City management is often ineffective. Urban infrastructure is becoming increasingly outdated, and PDAM Bandung is facing similar complex challenges.

\subsubsection{PDAM Tirtawening profile}

PDAM's core business is the supply chain business - notably balancing water supply and demand. Water supply management consists of managing water intake: water source management, water processing management and water distribution management. Water demand management consists of managing customers and their behavior, tariffs, customer service, customer debt collection, billing and 
payment management. Besides that, there is Non-Revenue Water (NRW) that is managed by PDAM.

NRW consist of physical and commercial leakages and losses caused by operational usage. Physical leakages consist of leaks occurring from PDAM's devices. This type of leak is caused by lack of control over the leaks, low operation and maintenance capability and low asset quality. Commercial leakage is caused by water theft, unregistered and unregulated connections, low meter accuracy, and errors in reading water meters as well as errors in the billing system. Water losses occur due to operational usage, such as accommodating the needs of the fire department or cleaning PDAM water treatment devices.

PDAM's Key Performance Indicators (KPIs) are standardized by Indonesian Public Works. One of the KPIs is to deliver their service to a minimum of $80 \%$ of the population.

\subsubsection{Water intake}

The supply of drinking water in Bandung municipality is filled from domestic drilling and is partly served by PDAM. PDAM water sources are obtained from both surface and ground water. PDAM pumps the ground water out of 10 water springs and 19 wells into the reservoirs.

\subsubsection{Water processing}

PDAM has 2 units of water treatment installation (Instalasi Pengolahan Air Minum/ IPA). Those units serve 5 regions, i.e. western, northern, central, southern and eastern Bandung. PDAM uses a gravitation system to take the surface water, and a pump system to obtain ground water. PDAM has 6 reservoirs with a total capacity of $42,600 \mathrm{~m}^{3}$.

These IPAs operate 24 hours a day and the process ends by flowing the treated water into the reservoirs. The KPI is water leakage, which cannot be more than $5 \%$ of the total water that flow out from the IPA.

\subsubsection{Water distribution}

Even though the IPAs operate 24 hours per day, distribution only lasts for 15 hours per day. Based on a previously conducted customer survey, Arifin et al. [20] found that some residential areas have water distribution for only 6 hours per day. This occurs due to unstable and low water supply, especially during the dry season.

This inconsistent water supply has resulted in PDAM requiring a waiver to be signed by new customers agreeing not to question PDAM's sub-optimal service. Such a waiver must be signed by prospective customers as a condition of applying for a new connection (Zonasi [3], BPKP [21]).

Non-revenue water in distribution now is around $50 \%$. To be considered as a good water management facility, the standard KPI for the NRW in distribution should be less than $15 \%$.

Due to limited water supply, the water consumption per capita per day is less than the standard. The standard for a city that has more than 1 million citizen is 150 liter/capita/day (PU [2]). 


\subsubsection{PDAM customers and water tariff}

There are different types of customers based on the market segment: social, residential and industry. Residential segment is divided to classes, categorized by house sizes and locations. Each category is charged by different tariff that is annually adjusted (i.e. rationalized) with the yearly national inflation rate. However, the actual adjustment is done only once per 5 years. The tariff rationale is approved by the city's parliament.

Based on the Indonesian Public Work Ministry (PU) standard, the water tariff should not be more than $4 \%$ of residential income. PDAM Tirtawening Bandung services covers only $62 \%$ of population. Based on the assumption taken by the PDAM calculation 1 house covers 6 people, while based on the customer survey done by the previous research, the average number of people in a house is only 3 or 4 (Arifin et al. [20]).

\section{Research approach}

Research on project portfolio management using PI has been utilizing static methods to describe causal relationships. Though these methods are simple and easily manipulated, in a dynamic and complex project system they have been proven to be less accurate and practical. This research will establish a system of project portfolio management using dynamic PI.

The first step is to establish the PDAM supply chain system analysis. The second step is to establish a causal relationship(s) within the system, describe the PI among PDAM supply chain projects and to analyze coupling and feedback relationships, the loop existing in the system, and to determine the final comprehensive relationship. The third step is to define the variables and develop a system dynamics model. The fourth step is the model analysis and its application, which aims for the relationship between some factors that deserve to be inspected by project portfolio managers.

\section{Analysis}

\subsection{System analysis}

The first step to use a system dynamics approach is to do a system analysis. The way a system works is explained in 1.4.2-1.4.6.

\subsection{Analysis of feedback structure}

PDAM's core business is the supply chain business. The supply variables consist of water intake volume, output of water processing installation (IPA), and output of water distribution, sales volume, and non-revenue water amount in IPA reservoir flow as well in reservoir - water distribution flow. The demand data is populated by the Bandung Municipality population data - that includes target customer and the current customer. All of those data cover also the yearly rate. The demand data is populated by the Bandung Municipality population data - that 
includes target customer and current customer information. All of the data includes also the yearly rate.

The demand-supply chain causal loop for the water management system at PDAM Tirtawening Bandung municipality case study is shown in Figure 1 below. The key feedback loops were set to mimic the unavailability of water to PDAM customer problem that was articulated in the problem definition. The development of causal loop diagrams allowed the project portfolio to be mapped as a means to understand the problem situation and assist in the preliminary investigation of the dynamic hypothesis. The causal loop diagrams clearly show that there is strong evidence of interdependency relationships between the projects identified in the problem articulation.

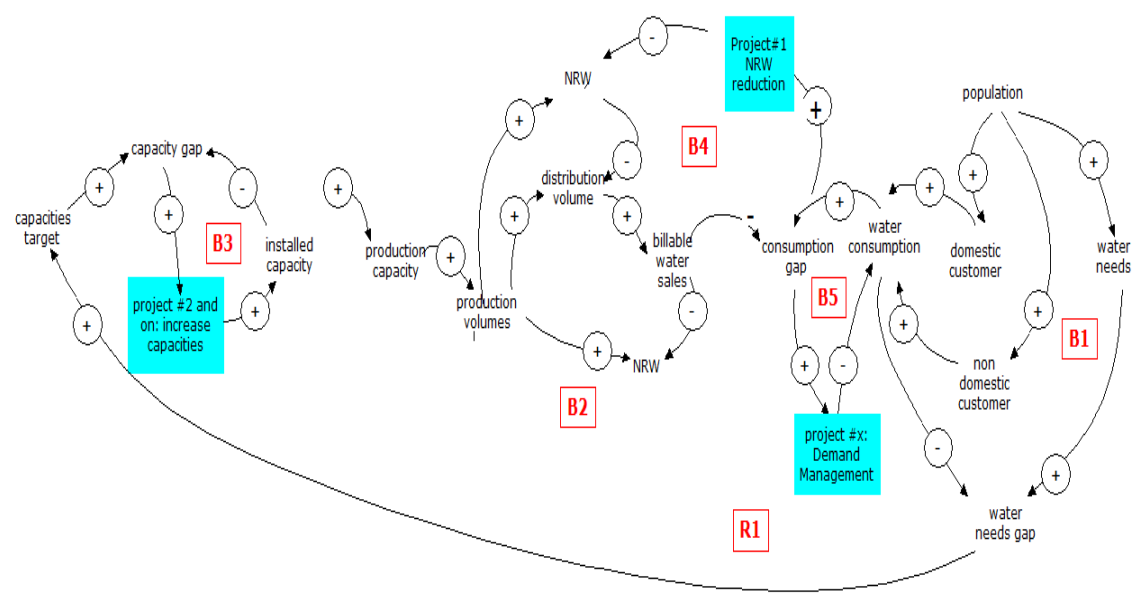

Figure 1: Water supply-demand interrelationship.

Once the causal loop is developed, the development of stock and flow is made based on the causal loop diagram. Example of stock and flow diagram is shown in Figure 2.

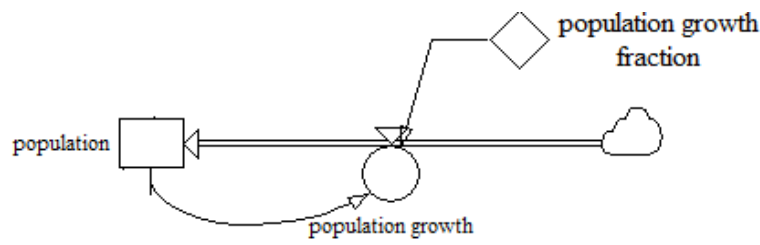

Figure 2: $\quad$ Example of stock and flow diagram.

\subsection{Model application}

Before applying or running the model, the model is validated. The validation is done by running the model using historical data (year 2000-2010), and by comparing the results with those using historical data. The difference between the 
model results and the historical data is lower than $10 \%$, while the absolute mean error's standard is $30 \%$ (Soesilo and Karuniasa [22]).

The model is developed using Powersim. The result is shown in Figure 3. It's obvious from Figure 3 that: 1) PDAM Tirtawening does not have more capability to set up new and breakthrough initiatives, outside of its daily maintenance. That's why the gap between demand and supply gets bigger over time; 2) Figure 3 also demonstrates a big gap (above 50\%), between water volume flowing out from the reservoir and water flowing into distribution; 3) The gap between water flows out from IPA to the water flow into the reservoir is higher than its KPI, which is $5 \%$ of IPA outflow; and 4) From Figure 3, it is obviously seen that until year 2025, the maximum capacity remains sufficient to supply $80 \%$ of the total demand (MDG standard).
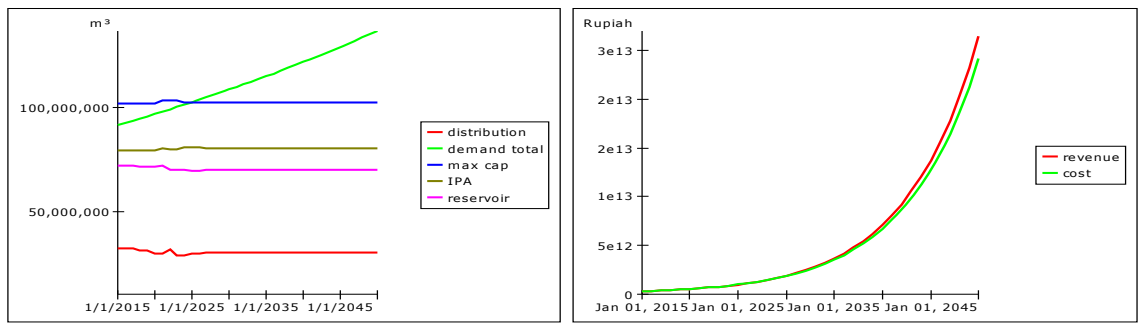

Figure 3: Business as usual model.

Based on Figure 3, we can see that to achieve the KPI, PDAM Tirtawening should develop investment planning with project selection and set its priorities as follows: 1) Project \#1: Reducing the non-revenue water program, parallel with the capacity improvement of the reservoir; 2) Project \#2: Increase the IPA capacity; 3) Project \#3: Increase the maximum capacity; and 4) Project \#4: Increase the number of customers using the new assets and resource capacity. These four projects are the drivers for other PDAM projects. Furthermore, this paper will explain the project portfolio scenarios of PDAM until project \#3.

\subsection{What if scenario}

"What if" scenarios allow the models to be evaluated in order to analyze plausible strategies that could be implemented into future systems. The project owner has the ability to try different policy decisions before making the mistake of investing in a potentially disastrous solution (Cai [15]).

Figure 4(a) explains a result of Project \#1a: To reduce the NRW in the distribution stage. Reducing the NRW in the distribution stage would produce additional distribution volume of more than $50 \%$, from 29.5 million $\mathrm{m}^{3}$ to 46.3 million $\mathrm{m}^{3}$ by the year 2025 . The gap between reservoirs to the distribution volumes remains significant after running the Project \#1a. To appease this issue, PDAM should run Project \#1b, together with Project \#1a. 


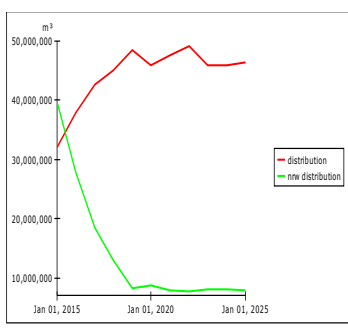

(4a). Distribution and NRW volumes resulted from project $\#$ la

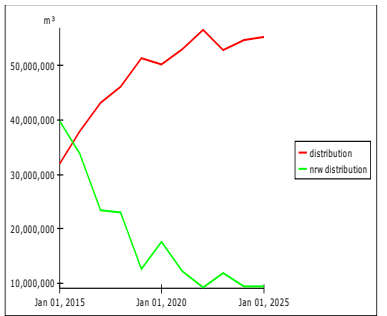

(4b). Vo,ume gaps resulted from project \# $1 \mathrm{~b}$

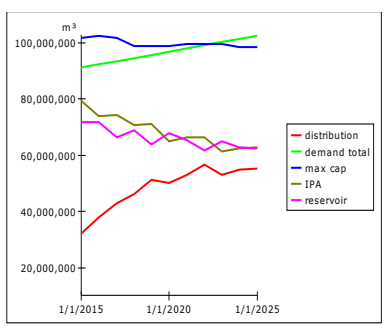

(4c). Vo,ume gaps resulted from project \#1b

Figure 4: “What-if” scenario of Project \#1.

Project \#1b aims to reduce the NRW between IPA and the reservoir. Both projects would produce additional distribution volume from 46.3 million $\mathrm{m}^{3}$ to 55.25 million $\mathrm{m}^{3}$ by the year 2025 (Figure 4(b)). The gap between reservoir and distribution volumes would remain significant (Figure 4(c)).

Figure 4(c) obviously shows that after the NRW are fixed, the gap between reservoir and distribution volumes remains large because the distribution capacity is not sufficient to receive the high rate of reservoir outflow.

To reduce the gap, the distribution capacity should be increased (project \#1c). Improving the distribution capacity would increase the distribution volume from 50 million $\mathrm{m}^{3}$ to 57.5 million $\mathrm{m}^{3}$ by the year 2020 (see Figure 5) - allowing PDAM to get their revenue earlier.
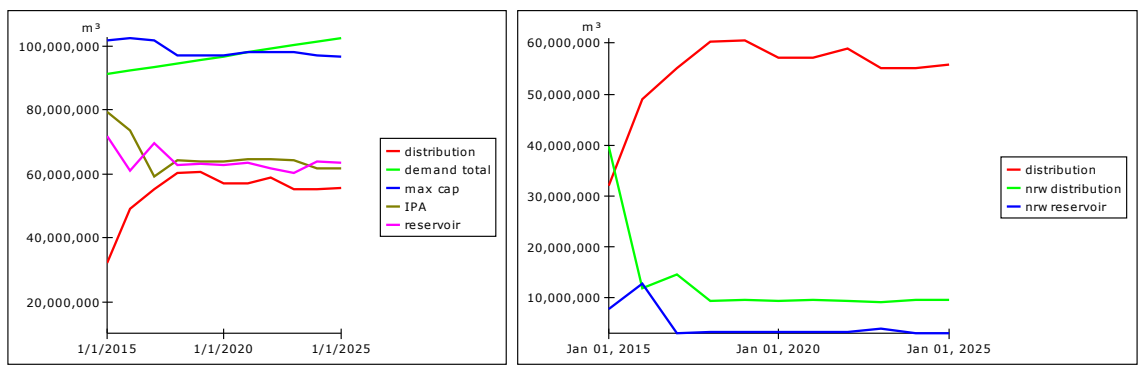

Figure 5: $\quad$ Result of Project \#1a, Project \#1b and Project \#1c.

By running Project \#1, PDAM is able to fulfill their KPI by reducing the NRW while producing additional revenue needed to fund their next projects. Their subsequent project would be Project \#2 and so on, which consist of IPA and intake capacity improvement.

Reiterating fine-tuning between the above processes, increasing the capacities of IPA and intake will subsequently lead to increasing the capacity of the reservoir and distribution processes. The result of the iteration in Project \#2, Project \#3 is shown in Figure 6.

Once the optimal project portfolio model is established, the next action is to calculate the profit and loss in order to make sure that the PDAM have added value from implementing these projects. 

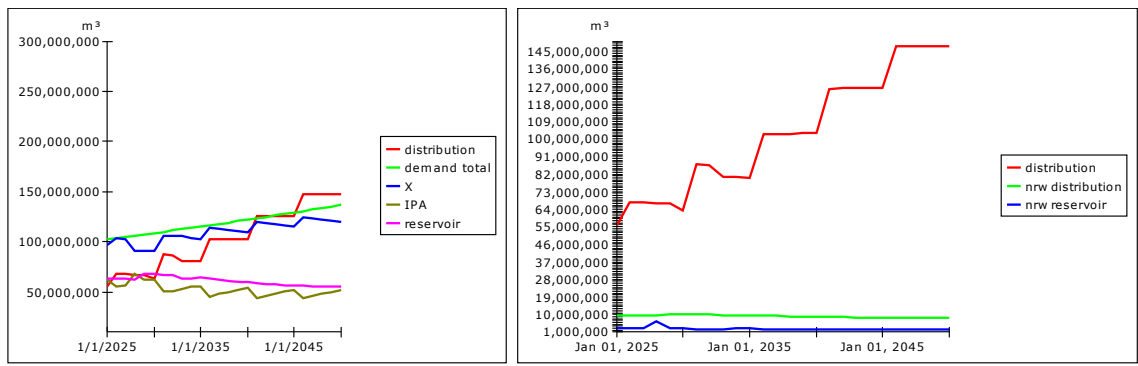

Figure 6: The result of Project \#2 and Project \#3.

\section{Findings}

The system dynamics approach has the capability to establish Project Portfolio Management (PPM). The advantage of using the system dynamics approach in establishing the PPM is that the organization will have clear, intuitive and interactive guidance on project selection and determining priorities. This approach is also able to support the dynamic changes of the organization's strategy. The model helps to predict the rate of increase of the PDAM supply capacity in order to fulfill the PDAM Tirtawening KPI(s).

The system dynamic testing, forecast analysis and "what-if" scenario investigations revealed the strong interdependency links between projects modelled within the scope of the PDAM Tirtawening Water Management System project portfolio. The results obtained from the scenario demonstrated that the effects of implementing the project to other projects in the portfolio are positively influenced and are strategically enhanced to increase their return on investment.

The "what-if" scenario provided a foundation to question the portfolio and test the interdependency relationships between the projects. By doing so, the project portfolio selection, priority and project interdependencies could be better understood by all stakeholders

\section{Conclusion}

a) The study reveals that water shortage is becoming an increasingly serious issue in Bandung municipality. Demand has been growing fast along with the growth of the population, while water availability is rapidly decreasing due to pollution, changes in land use, and shared water supply with Bandung hinterlands that are developing very rapidly as well.

b) Project Portfolio Management should be able to show the dynamic changes in the environment faced by the organization. Project Portfolio Management development using the system dynamics approach is able to fulfil this expectation.

c) In order to align to the environment that changes dynamically, project portfolio should be monitored and fine-tuned properly over time, because project 
portfolio is very sensitive to the changes and changes on the project directly impact to the other projects.

d) Project Interdependencies always appear among projects within project portfolios. If the projects within a portfolio are independent, then there would be no use in selecting and determining project priority. The interdependencies among projects can be driven by use of the same resources, same competencies, project results, and interdependencies on KPI, organization goal, market, strategic partners, and others. Project interdependencies should be assessed accurately when developing a project portfolio.

e) Since PDAM is experiencing an inadequate water supply and maintenance of the delivery system, it is suggested to control properly the NRW.

f) After all, there should be a strong government policy for urban water management, an appropriate adaptation strategy and a political will to implement the strategy.

\section{Recommendation}

Because the system dynamics runs interactively, this tools able to help organization to obtain the same understanding among organization stakeholders in managing the project portfolio.

The dynamic project portfolio management should be applied in PDAM, especially in PDAM Tirtawening Bandung Municipality, to enhance the organization capabilities in selecting and prioritizing their projects, in order to achieve the targeted Key Performance Indicators.

\section{References}

[1] UN, International years of fresh water 2003, http://www.un.org/events/ water/brochure.htm, 2003.

[2] PU, BPPSPAM, Kinerja PDAM tahun 2008 - 2010, Kementerian Pekerjaan Umum, Jakarta, 2008-2010.

[3] PT. Zonasi, Laporan Akhir Rencana Induk Air Minum PDAM Tirtawening Kota Bandung, PT. Zonasi, Bandung, 2009.

[4] PMBOK, Project Management Body of Knowledge 5th Edition, Newton Square, Pennsylvania: Project Management Institute Inc, 2013.

[5] PMI, The Standard for Portfolio Management - Third Edition, Pennsylvania: Project Management Institute, Inc., 2013.

[6] Bert Kersten, Chris Verhoef, IT Portfolio Management: A Bankers perspective on IT, Get the Cutter Edge, vol. 16, no. 4, pp. 27-33, 2003.

[7] Laslo, Zohar, Project portfolio management: An integrated method for resource planning and scheduling to minimize planning/schedulingdependent expenses, International Journal of Project Management, vol. 28, pp. 609-618, 2010.

[8] Platje, Adri, Project and Portfolio Planning Cycle, Netherland: International Journal of Project Management, 1994. 
[9] F. Ghamsemzadeh, N. Ancher, an Integrated framework for project portfolio selection, Great Britain: International Journal of project management, 1999.

[10] P. Carlsson, C, Fuller, R, Heikkila, M, Majlender, A Fuzzy Approach to R\&D project portfolio selection, Science Direct, International Journal of Approximate Reasoning, 44, pp. 93-105, 2007.

[11] G.V. Zapata, J.C, Varma, V.A, Reklaitis, Impact of Tactical and operational policies in selection of new product portfolio, Science Direct, Computers and Chemical Engineering, 32, pp. 307-319, 2007.

[12] Mait Rungi, Olli-Pekka Hilmola, Interdependency management of projects: survey comparison between Estonia and Finland, The current issue and full text archive of this journal is available at www.emeraldinsight.com/ 1746-5265.htm, pp. 146-162, 2011.

[13] Catherine P Killen, Cai Kjaer, Understanding project interdependencies: exploring the role of visual, International Journal of Project Management, 2012.

[14] Simon Coldrick, Philip Longhurst, An R\&D options selection model for investment decisions, technovation science direct, vol. 25, no. 3, pp. 185193, 2005.

[15] Cai, Zhiming, System Dynamics (SD) and its Application, AMEC, Knutsford, Cheshire.

[16] U. Srijariya, W. Riewpaiboon, A. Chaikledkaew, System Dynamic: an Alternative Method of Budgeting, Journal of Value in Health, Vol 11 Supplement 1, pp. 115-123, 2008.

[17] J. Sterman, Business Dynamics: Systems Thinking and Modelling for a complex world, McGraw Hills Company Inc, USA, 2000.

[18] G. Papageorgiou, Toward a System Dynamics modelling framework for effective political organisation management strategies, Journal of Political Marketing 9:1, pp. 55-72, 2010.

[19] Bandung, Badan Pusat Statistik Kota, Bandung Dalam Angka 1999-2011.

[20] R S. Arifin, S. M. Moersidik, D. M. Hartono, Y. Latief, Determinants of Residential Water Consumption: Analysis from Municipal Waterworks (PDAM), SYLWAN journal Vol. 159, Issue. 1, 2015.

[21] BPKP, Laporan Hasil Audit Kinerja Atas Perusahaan Daerah Air Minum (PDAM) Kota Bandung, Tahun Buku 1995-2010, Badan Pemeriksa Keuangan Pembangunan, Jawa Barat, 1995-2010.

[22] T.E.B. Soesilo, M. Karuniasa, Pemodelan System Dynamics, Jakarta: Lembaga Penerbit Fakultas Ekonomi Universitas Indonesia, 2014. 